ppi $201502 Z U 4645$

Esta publicación científica en formato digital es continuidad de la revista impresa ISSN-Versión Impresa 0798-1406 / ISSN-Versión on line 2542-3185Depósito legal pp $197402 Z$ U34

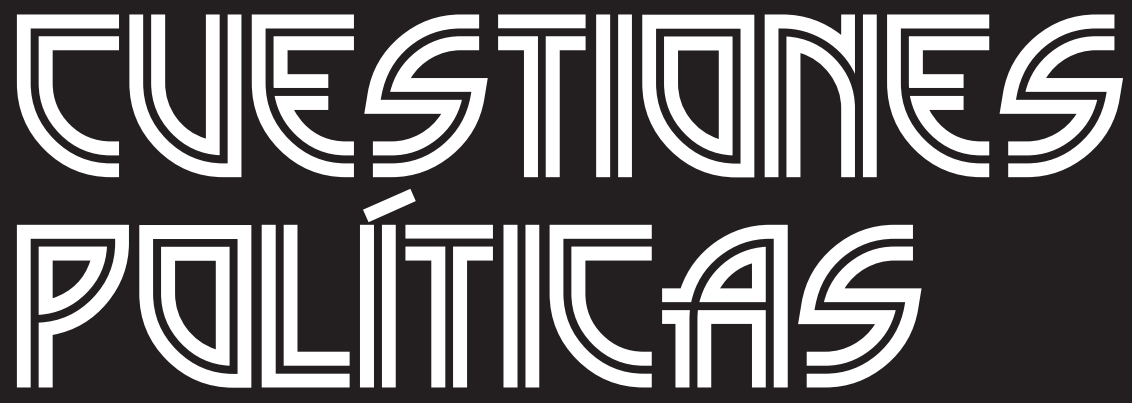

Instituto de Estudios Políticos y Derecho Público "Dr. Humberto J. La Roche" de la Facultad de Ciencias Jurídicas y Políticas de la Universidad del Zulia Maracaibo, Venezuela
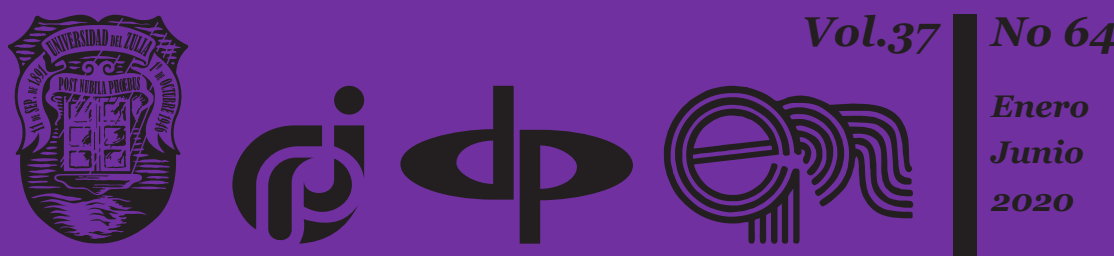


\title{
Political implications of the development of the linguistic competence of students in the educational complex
}

\author{
Poliakova Ia.V. * \\ Shugaeva E.A. ** \\ Azmetova R.F.*** \\ Yanova E.A. **** \\ Klimakina E.A. ***** \\ Pashneva S.A. ${ }^{* * * * * *}$ \\ Kovalenko I.V. ${ }^{* * * * * * *}$
}

\section{Abstract}

In modern conditions of rapid development of international contacts and ties in culture, politics, economics and other spheres, practical knowledge of foreign languages becomes a real necessity and an indispensable condition for a successful career. Educators and researchers in recent decades have increasingly focused on the unity of motivational-cognitive and behavioral components in the graduate's personality structure. The broader concepts reflecting this unit turned out to be "competence" and "being competent." Contextual analysis of the concepts "competence" and "professional competence" indicates that various approaches to their interpretation have now been developed. The competence-action approach could implement the conceptual idea of modernizing the teaching and learning process, that is, ensuring mastery of communicative activities through the development of a set of competences focused on opportunities, skills, needs, cognitive activity and creativity of the students with clear political implications. It is concluded that, the competence in foreign languages is based on the development of constitutive

* Candidate of Pedagogical Sciences, Associate Professor, Donetsk Pedagogical Institute (Donetsk, DPR), Email: donpi_dnr@mail.ru.

** Candidate of Philology Sciences, Associate Professor, K.G. Razumovsky Moscow State University of Technologies and Management (the First Cossack University), Email: rektorat@mgutm.ru.

*** Candidate of Sociology Sciences, Associate Professor, K.G. Razumovsky Moscow State University of Technologies and Management (the First Cossack University), Email: rektorat@mgutm.ru.

**** Senior Lecturer, K.G. Razumovsky Moscow State University of technologies and management (the First Cossack University), Email: rektorat@mgutm.ru.

***** Candidate of Philology Sciences, Associate Professor, K.G. Razumovsky Moscow State University of Technologies and Management (the First Cossack University), Email: rektorat@mgutm.ru.

****** Candidate of Philology Sciences, Associate Professor, Kursk State University, Email: info@ kursksu.ru.

******* Head Teacher of Social Pedagogy Department, The Institute Of Foreign Languages, Peoples' Friendship University Of Russia, Email: rector.office@rudn.ru. 
Poliakova Ia.V., Shugaeva E.A., Azmetova R.F., Yanova E.A., Klimakina E.A., Pashneva S.A. y Kovalenko I.V.

Political implications of the development of the linguistic competence of students in the

capacities, such as: linguistic, communicative, transcultural, sociocultural, intellectual, educational, professional and critical thinking.

Keywords: professional activity; critical thinking; language and power relations; proficiency in foreign languages; educational complex.

\section{Implicaciones politicas del desarrollo de la competencia lingüística de los estudiantes en el complejo educativo}

\section{Resumen}

En las condiciones modernas de rápido desarrollo de contactos y lazos internacionales en la cultura, la política, la economía y otras esferas, el conocimiento práctico de idiomas extranjeros se convierte en una necesidad real y una condición indispensable para una carrera exitosa. Los educadores e investigadores en las últimas décadas se han centrado cada vez más en la unidad de componentes motivacionales-cognitivos y conductuales en la estructura de la personalidad del graduado. Los conceptos más amplios que reflejan esta unidad resultaron ser "competencia" y "ser competente". El análisis contextual de los conceptos "competencia" y "competencia profesional" indica que ahora se han desarrollado varios enfoques para su interpretación. El enfoque de competencia-acción podría implementar la idea conceptual de modernizar el proceso de enseñanza y aprendizaje, es decir, asegurar el dominio de las actividades comunicativas a través del desarrollo de un conjunto de competencias centradas en las oportunidades, habilidades, necesidades, actividad cognitiva y creatividad de los estudiantes con claras implicaciones políticas. Se concluye que, la competencia en lenguas extranjeras se basa en el desarrollo de capacidades constitutivas, tales como: lingüística, comunicativa, transcultural, sociocultural, intelectual, educativa, profesional y de pensamiento crítico.

Palabras clave: actividad profesional; pensamiento crítico; lenguaje y relaciones de poder; competencia en idiomas extranjeros; complejo educativo. 


\section{Introduction}

In the modern world of rapidly developing international contacts and ties in culture, politics, economics and other spheres, practical knowledge of foreign languages becomes a real necessity and indispensable condition for successful career (Sergeeva \& Trubakova, 2017; Badakhova, 2017; Gadzhieva, 2018; Osipova, 2018; Borisova et al, 2018; Borovikova, 2017; Larskikh \& Larina, 2017). Modern specialist is faced with tasks of great complexity. It is necessary to study advanced technologies, adopt everything new that has been accumulated in the world. In order for Russian enterprises to compete with the best foreign companies, each specialist must know what is done, what is planned in the relevant professional areas. Practice has shown that in the professional world, it's not just translators who are more useful, but qualified specialists fluent in foreign languages. The foreign language competency of a professional is in greater demand than ever at the present stage of the economic development of Russia. Practical knowledge of foreign languages, on the one hand, helps to increase the level of professional competency, on the other hand, involves the ability to implement such aspects of professional activity as timely acquaintance with new trends and establishing contacts with foreign companies and entrepreneurs, dialogue with foreign colleagues (Zimniaya, 2000).

Requirements for the foreign languages knowledge by graduate students of vocational educational organizations whose professional activities are related to the sphere of domestic services and catering have increased significantly. The competitiveness of future specialists to a large extent depends on the level of their general culture and knowledge of foreign languages. When applying for a job, for example, as a technologist for catering, a hairstyling artist or a cosmetologist, makeup artist for a joint venture, knowledge of foreign languages is often a decisive factor.

It is generally recognized that foreign language competency has become a kind of productive force, and foreign language literacy could be considered as an economic category. Therefore, students of vocational schools should acquire a level of communicative foreign language competency that would allow them to use a foreign language as an additional means of improving their professional qualifications. Thus, the social order makes new demands on the system of foreign language teaching and stimulates the search for rational ways of organizing and developing its target and motivational sides (Yazovskikh, 2018; Gadzaov \& Dzerzhinskaya, 2018; Gasanova et al, 2017; Gnatyuk \& Pekert, 2018; Kryuchkova, 2018; Kuznetsov et al, 2018).

The First Moscow Educational Complex is a professional institution, which includes Technological College, College of Art Crafts, Moscow Art and Pedagogical College of Technology and Design, College of Entrepreneurship, secondary school with in-depth study of English. 
Poliakova Ia.V., Shugaeva E.A., Azmetova R.F., Yanova E.A., Klimakina E.A., Pashneva S.A. y Kovalenko I.V.

Political implications of the development of the linguistic competence of students in the 184 educational complex

For any student, the ultimate educational goal is to acquire knowledge and skills in the chosen profession. Therefore, the leading motive in learning foreign languages in the First Moscow Educational Complex should be the acquisition of knowledge in the field of future profession. However, the mismatch remains between the undeveloped problem of teaching a professionally oriented foreign language course in vocational schools both in theoretical and practical terms, and the need to achieve sufficiently high final goals, i.e. practical knowledge of a foreign language in the professional field. The practical implementation of these goals is also complicated by the limited duration of training, the lack of specialized textbooks, teaching aids and recommendations on working with special literature on the subject for a number of specialties in the Educational Complex, including consumer services, fashion and catering (Scherbakova, 2002).

In our opinion, the implementation of professionally oriented content of a foreign language course in the Educational Complex is possible on the basis of interdisciplinary integration of foreign languages and specialized disciplines. Only in this case, the language material will contain new and necessary professional information for students. The role of the informational value of educational material in the process of foreign language teaching is well correlated with the most important function of the language as a means of communication, the main attribute of which, as we know, is the need to obtain and exchange necessary information.

Purposeful, consistent and systematic work on the selection of professionally oriented content of language material, and the teaching methods corresponding to this material will contribute to the development of the stable motivation system for learning a foreign language.

\section{Literature Review}

The competency-action approach to teaching foreign languages will be able to implement the conceptual idea of modernizing the learning process: to ensure the mastery of communicative activities through the development of a set of competencies focusing on the capabilities, abilities, needs, cognitive activity and creativity of students.

We consider foreign language competency as a set of competencies that a future mid-level professional should master. In the modern scientific literature in the field of philology and methods of foreign language teaching, the terms "competency" and "being competent" are widely used to determine various aspects: "foreign language professional communicative competency" (O.Yu. Iskanderova), "sociolinguistic competency" (E.Yu. 
Panina), "social competency" (M.V. Druzhinina), etc. We use the term "foreign language competency" in our research work, since our goal is not only the linguistic knowledge (linguistic competency), but also the versatile development of personality and possibilities of applying the acquired knowledge of foreign languages in future career. Important indicators of the foreign language competency are the need for the active use of existing knowledge to solve practical problems, knowledge demands for the upcoming professional activity, the ability to perform the substantive and socially meaningful work (Amelchonok, 1974)

Dynamic changes in the social and economic life of Russia determined such requirements for a mid-level professional of innovative type, where the linguo-didactic competency is more than ever demanded not only by an individual, but also by the society. Foreign language skills will help quickly adapt to the modern professional world and successfully carry out professional functions, acquire greater competency in future professional career, to form a methodological and psychological readiness to change the type and nature of their professional activities. Knowledge of foreign languages also helps to increase the general competency of a future specialist, which is a powerful reserve for accelerating economic, cultural and social development of both individual professional areas and the entire state. Therefore, it can rightfully be argued that foreign language competency is an economic category (Ksenzova, 2001).

Our approach to the development of foreign language competency reflects such progressive ideas of improving the modern system of Russian education as lifelong education and forward-looking education. The main meaning of lifelong education is constant development and improvement of each person throughout life, education through life. The development of foreign language competency in the context of lifelong education can be viewed from two sides. Firstly, this is the continuity of educational activities, curricula, plans, content of subjects during the transition of students from one stage of teaching and learning a foreign language to another (primary school - secondary school - vocational institution - university). Secondly, it is a constant continuous self-education, the decision of each person to advance in the level of knowledge of foreign languages, the ability to achieve a high level of foreign language competency and upgrade the profile of education or professional activity, based on personal needs and opportunities and requirements of the labor market (Borisova et al, 2018).

Forward-looking education purposefully prepares students for the social and professional activities that require a wider and at the same time flexible educational base, continuous development, readiness for adaptation in challenging working conditions. Foreign language is a universal means of enhancing the possibilities of professional career and socialization. 
Poliakova Ia.V., Shugaeva E.A., Azmetova R.F., Yanova E.A., Klimakina E.A., Pashneva S.A. y Kovalenko I.V.

Political implications of the development of the linguistic competence of students in the

The competency-based education began its formation in 1965 at the University of Massachusetts (USA) with the concept of "competency" proposed by N. Chomsky in relation to language theory and transformational grammar (Chomsky, 1972). In addition, N. Khomsky determined the understanding of the differences between the concepts of "competency" and "performance" (in our terms understood as "being competent"), where the latter is interpreted as a knowledge-based, intellectually and personally determined experience of social and professional life (Artyomov, 1969).

At the symposium in Berne (1996), W. Hutmacher in the summary report noted that the very concept of competency, being a part of such concepts as skills, mastery, ability, has not been clearly defined to date. The notion of competency lies fairly firmly within the field of "knowing how" rather than "knowing that". Modernization of Russian education and the federal state educational standards provide a detailed description of the role and place of the key (basic, universal) competencies of a specialist (Kolkova, 2003).

The methodological grounds of this study are the following:

- the theory of speech activity in general psychology (L.S. Vygotsky, A.N. Leontiev, A.A. Smirnov, A.N. Sokolov);

- the theory of psychological prerequisites for the activation of learning a foreign language (V.A. Artemov, B.V. Belyaeva, I.A. Zimniaya);

- general methodological principles of teaching a foreign language (L.V. Shcherba, I.V. Rakhmanov, I.M. Berman, A.A. Mirolyubov);

- the concept of information-target approach to professionally oriented texts (T.M. Dridze, T.S. Serova, E.Yu. Dolmatovskaya);

- the theory of systematic approach to the analysis of socio-pedagogical processes (Yu.K. Babansky, V.V. Kraevsky, I.I. Logvinov, M.N. Skatkin and others);

- the concepts of pedagogical innovations (V.V. Davydov, V.I. Zagvyazinsky, P.I. Pidkasisty, D.V. Elkonin and others),

- the fundamentals of professional education (S.Ya. Batyshev, A.P. Belyaeva, A.M. Novikov, T.Yu. Lomakina, L.G. Semushina, G.V. Mukhametzyanova, V.A. Polyakov, I.P. Smirnov, etc.),

- the concept of continuous vocational education (A.P. Vladislavlev, V.M. Zhurakovsky, A.A. Kirsanov, E.V. Tkachenko),

- key competencies (I.L. Bim, M.N. Vatyutnev, E.F. Zeer, I. A. Zimniaya, E.A. Klimov) (Belyaev, 1965). 


\section{Proposed Methodology}

The urgent task of the vocational education system in Russia is to improve the quality of vocational training. The quality of vocational education is based on a complex multilevel and dynamic system focused on providing the quality of graduate, which is determined by the degree of compliance with the goals and results of education. It is the goal that determines the forms, means, content of the educational process and, of course, the results of education. Defining the goals and results of education, in the last decades researchers have been paying increasing attention to the unity of motivational-cognitive and behavioral components in the structure of the graduate's personality. The most capacious concepts reflecting this unity turned out to be the concepts of "competency" and "being competent" (Kitaygorodskaya, 1982).

Contextual analysis the concepts "competency", "being competent" and "professional competencies" in pedagogical, psychological, reference, etc. sources indicates that to date there are various approaches to their interpretation, which create difficulties in their systematization and hierarchical sequence. Despite the fact that the semantic load is different, sometimes interchangeability of these notions occurs. Russian educators include in the concept of "competency", in addition to professional knowledge and skills, such personal traits as orientation (motivation, values, etc.), the ability to overcome stereotypes, insight, flexibility of thinking, character (independence, determination, will, etc.). The term "competency" means the result of cognitive activity, knowledge and experience of a person in any field, and "being competent" means the ability to apply this knowledge and experience in the chosen field of knowledge or career. Being competent implies, in addition to professional technological training of a specialist, such personality traits that are necessary for any specialist today (Badakhova, 2017).

It should be noted that these terms are widely used in modern scientific and methodological literature in the field of education as a qualitative indicator of knowledge and skills of students or graduates. The level and quality of training is usually defined by the term "qualification". However, the broader term "competency" is increasingly used, which includes, in addition to purely professional knowledge and skills that characterize qualifications, such qualities as initiative, cooperation, ability to work in a team, communication skills, ability to learn, think logically, evaluate, select and use information, etc. Professional competency should include, first of all, high-level professional skills, the ability to further development in the profession, to communicate professionally, to bear professional responsibility for the results. The most general criterion of professional 
Poliakova Ia.V., Shugaeva E.A., Azmetova R.F., Yanova E.A., Klimakina E.A., Pashneva S.A. y Kovalenko I.V.

Political implications of the development of the linguistic competence of students in the

competency is professional adaptation, the ability to work according to certain moral and professional economic guidelines. In general, competency appears in its various forms of manifestation, and professional competency, in particular, appears in a form adequate to the chosen profession.

Therefore, starting from the first stage of training, it is necessary, first of all, to develop students' motivational sphere: interest, awareness of the career choice. In addition, developing the professional skills and abilities, vocational educational institution will help a future professional to quickly adapt to the appropriate professional environment.

The strategy for the modern development of vocational education in Russia focuses on the preservation of fundamentality and the simultaneous strengthening of a practical orientation based on the development of a set of competencies. That is, we can say that the modernization of education is carried out from the standpoint of a competency-based approach. The content of education is the basis for the development of competency (or a set of competencies) of students, and the process of mastering the profession is activity-based.

\section{Result Analysis}

The professional career of a graduate of the First Moscow Educational Complex extends mainly to the sphere of consumer services, aimed at meeting the needs of consumers.

In accordance with fundamental and special training, graduates will perform the following types of professional activities: production and technology, performing arts, mid-level management.

The main socio-economic and psychological-pedagogical requirements of professional education in this area are:

- compliance of existing knowledge with the needs of the market;

- multifunctionality;

- ability to respond quickly to changing fashion trends, styles and the demand of consumer services;

- ability to adapt to new types and conditions of professional activity;

- readiness for continuous improvement of professional skills and mastery of new knowledge;

- professional responsibility for the results of work, which are associated with maintaining the health and appearance of consumer; 
- high level of artistic perception and aesthetic taste;

- ability to form an artistic image of a person;

- ability to quickly navigate the flow of information and implement it in professional activities;

- knowledge of information technologies and foreign languages in the professional sphere; competitiveness.

As can be seen from the list of socio-economic, psychological and pedagogical requirements of vocational education in the field of services and catering, graduates of the Educational Complex quickly respond to all the latest fashion trends and new technologies in the field of their professional career (modeling hairstyles, cosmetics and visage, modeling and designing clothes or cooking technology). Knowledge and processing of the most upto-date technologies and information in the professional field is the key to the competitiveness.

As graduates and students of the Educational Complex believe, one of the effective means of improving professional competency is a foreign language. Foreign language is in demand in the service sector in performing such types of professional activities as obtaining relevant information on the websites of foreign companies, exchange of information with foreign colleagues via e-mail, reading foreign publications, study of annotations and instructions for the use of professional products and equipment in a foreign language, participation in international competitions of professional excellence and communication with foreign colleagues, internships abroad, work in a joint venture and abroad.

Thus, knowledge of foreign languages is an important factor in increasing the competitiveness and prestige of a specialist in the service and catering sector.

Foreign Language teacher at the First Moscow Educational Complex Nina Scherbakova conducted the analysis of the curriculum for main specialties, which made it possible to compose the denotation cards (logical graphical schemes) reflecting the specifics of each specialty and clearly demonstrating the prospects of interdisciplinary coordination of Foreign Language with special disciplines (Shcherbakova \& Zvenigorodskaya, 2003). 
Poliakova Ia.V., Shugaeva E.A., Azmetova R.F., Yanova E.A., Klimakina E.A., Pashneva S.A. y Kovalenko I.V.

Political implications of the development of the linguistic competence of students in the

Table 1. The denotation card for the specialization "Food industry. Food Technology"

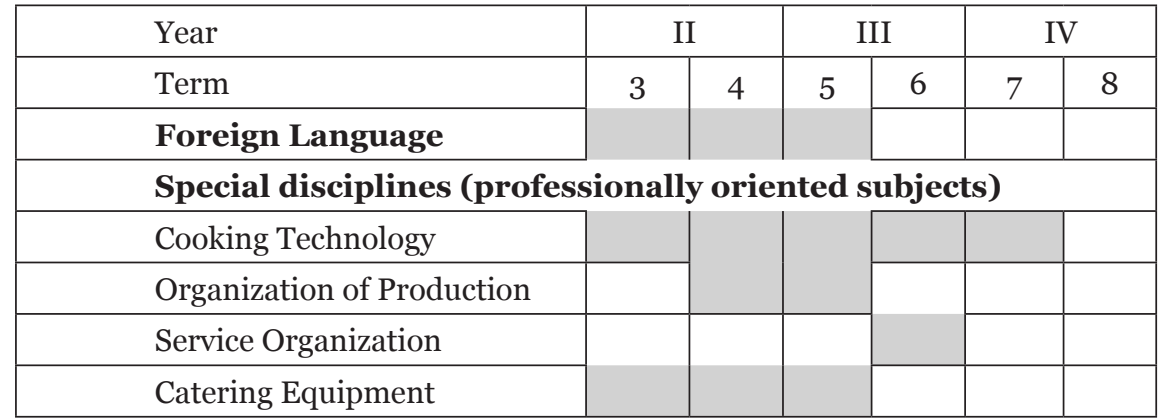

Own elaboration, 2019.

Table 2. Specialization denotation card "Hairdressing"

\begin{tabular}{|c|c|c|c|c|c|c|}
\hline Year & \multicolumn{2}{|c|}{ II } & \multicolumn{2}{|c|}{ III } & \multicolumn{2}{|c|}{ IV } \\
\hline Term & 3 & 4 & 5 & 6 & 7 & 8 \\
\hline Foreign Language & & & & & & \\
\hline \multicolumn{7}{|c|}{ Special disciplines (professionally oriented subjects) } \\
\hline Hairdressing Technology & & & & & & \\
\hline Materials Science & & & & & & \\
\hline Workshop & & & & & & \\
\hline Decorative Cosmetics & & & & & & \\
\hline
\end{tabular}

Table 3. Specialization denotation card "Modeling and designing garments"

\begin{tabular}{|c|c|c|c|c|c|c|}
\hline Year & \multicolumn{2}{|c|}{ II } & \multicolumn{2}{|c|}{ III } & \multicolumn{2}{|c|}{ IV } \\
\hline Term & 3 & 4 & 5 & 6 & 7 & 8 \\
\hline Foreign Language & & & & & & \\
\hline \multicolumn{7}{|c|}{ Special disciplines (professionally oriented subjects) } \\
\hline Designing Clothes & & & & & & \\
\hline $\begin{array}{l}\text { Modeling and Decoration of } \\
\text { Clothes }\end{array}$ & & & & & & \\
\hline Garment Technology & & & & & & \\
\hline Sewing Equipment & & & & & & \\
\hline
\end{tabular}


Table 4. Specialty denotation card "Cosmetics and makeup art"

\begin{tabular}{|c|c|c|c|c|}
\hline Year & \multicolumn{2}{|c|}{ II } & \multicolumn{2}{|c|}{ III } \\
\hline Term & 3 & 4 & 5 & 6 \\
\hline Foreign Language & & & & \\
\hline \multicolumn{5}{|c|}{ Special disciplines (professionally oriented subjects) } \\
\hline $\begin{array}{l}\text { Technological Equipment and } \\
\text { Materials Science }\end{array}$ & & & & \\
\hline Procedure Technology & & & & \\
\hline $\begin{array}{l}\text { Decorative Cosmetics and } \\
\text { Makeup }\end{array}$ & & & & \\
\hline Manicure Technology & & & & \\
\hline Pedicure Technology & & & & \\
\hline
\end{tabular}

Own elaboration, 2019.

The compiled denotation maps revealed the sequence of studying special disciplines and Foreign Language. For example, in accordance with the curriculum for the specialty "Food Industry. Technology of catering products" Foreign Language is studied at the II and III years (terms 3,4,5). In parallel with the discipline "Foreign Language", special disciplines "Cooking Technology" (terms 3-8), "Organization of Production" (terms 4, 5), "Equipment of Public Catering Enterprises" (terms 3, 4, 5) are studied. The discipline "Service Organization" is studied in the $6^{\text {th }}$ term, that is, it does not coincide with the period of studying Foreign Language. However, the content of this discipline includes a number of professionally oriented topics which are of great importance for the future professional activities of students, Therefore we include them in the Foreign Language syllabus. For example, the requirements for serving all kinds of consumers, table setting, professional and speech etiquette, business etiquette. Since the study of these topics in a foreign language will be ahead of their study in Russian, a foreign language teacher should learn the content of this discipline, the basic norms and requirements for the organization of modern catering, and proceed with the selection of educational language material after consulting a teacher of this discipline . 
Poliakova Ia.V., Shugaeva E.A., Azmetova R.F., Yanova E.A., Klimakina E.A., Pashneva S.A. y Kovalenko I.V.

Political implications of the development of the linguistic competence of students in the

\section{Conclusion}

Linguodidactic, pedagogical, psychological and other scientific areas emphasize the need to develop social competency. The content of education should create sufficient and necessary conditions for socialization both during training and in professional activities.

The main purpose of foreign language as a discipline is to acquire ability to communicate. We mean in this case the development of communicative competency, that is, the ability and willingness to take part in both direct communication (speaking, listening comprehension) and indirect communication (reading and understanding of foreign texts, writing). Communicative competency includes communication skills, the ability to establish vertical and horizontal contacts, adaptation to a specific sociopsychological situation, motives for behavior, interests, and the ability to understand a person. Foreign language contributes to the development of communicative competency, the ability to build personal and business communication with people, mastering various communication techniques depending on the field and type of activity (professional, managerial, social, etc.)

Acquaintance with the original professional literature develops the ability to understand other national cultures, forming cross-cultural competency.

Knowledge about the countries of the target language, as well as everyday life of the people of this country, behavior and speech etiquette standards, the achievements in various areas of public life and in the field of the profession being studied, customs and traditions, national culture contributes to the development of socio-cultural competency.

Learning foreign language is intellectual work aimed at mastering knowledge about the system of foreign language and at obtaining new information through foreign language tools and ways of expressing it, so we can rightfully speak about the development of intellectual competency.

The mandatory component of foreign language teaching and learning is the educational competency of students. The process of mastering professionally oriented foreign language involves the ability to independent, autonomous learning of the language and culture, which provides the conditions for its more fluent use.

The specificity of the discipline "Foreign Language" in a secondary vocational educational institution is determined by its professional orientation. Reading professionally-oriented literature and extracting new information from it, students enhance their professional competency. 
Foreign language contains a huge potential that can expand the professional horizons of a future specialist.

The development of foreign language competency of students in the Educational Complex occurs in the process of the formation of such constituent competencies as linguistic, communicative, cross-cultural, socio-linguistic, intellectual, educational, professional. The readiness and ability of the graduate to apply these competencies in practice are important indicators of the development of foreign language competency.

\section{Bibliographic References}

AMELCHONOK, Arina Antoni. 1974. To the problem of teaching reading in a foreign language, taking into account the specialty. In: Methods of teaching foreign languages. Issue 4, Minsk, pp. 45-48.

ARTYOMOV, Vlademir Albina. 1969. Psychology of teaching foreign languages. "Prosveshchenie". Moscow, Russia. 279 p.

BADAKHOVA, Irina Tatiana. 2017. Formation of Professionally Significant Qualities of Future Managers in the Training Process Forming. In: Modern Scientist. Issue 7, pp. 81-84.

BELYAEV, Barbara Valery. 1965. Essays on the psychology of teaching foreign languages. "Prosveshchenie". Moscow, Russia. 226 p.

BORISOVA, Mikaeil Alademir; MUSOKHRANOV, A.Yu; SIDOROVA, N.A. 2018. Use of fitness directions elements on physical education classes and their psychomatic impact on students of the special medical group. In: Modern Scientist. Issue 1, pp. 6-9.

BOROVIKOVA, Taisiya Valery. 2017. Methodological bases of formation of the intellectual potential of territories in the conditions of innovative economy. Modern Economy Success. Issue 6, pp. 46-49.

CHOMSKY, Noam. 1972. Aspects of the Theory of Syntax. MSU. Moscow, Russia.

GADZAOV, Alexander Fabio; DZERZHINSKAYA, M.R. 2018. Mathematical methods of analysis of the periodic components of economic processes. In: Modern Economy Success. Issue 1, pp. 14-18.

GADZHIEVA, olga Marshal. 2018. Socialization of personality as a factor in the mental, intellectual and spiritual-moral development. In: International Journal of Medicine and Psychology. Vol. 1. Issue 2, pp. 17-20. 
Poliakova Ia.V., Shugaeva E.A., Azmetova R.F., Yanova E.A., Klimakina E.A., Pashneva S.A. y Kovalenko I.V.

Political implications of the development of the linguistic competence of students in the

GASANOVA, Pavel Gulnara DAUDOVA, D.M; KABIEVA, R.A; TSAHAEVA, A.A. 2017. Moral qualities of businessmen in public con-sciousness. In: Modern Scientist. Vol. 1. Issue 1, pp. 209-211.

GNATYUK, Sergei Natalia; PEKERT, N.A. 2018. Education as a factor of sustainable development of agriculture. In:Russian Economic Bulletin. Vol. 1. Issue 3, pp. 18-27.

KITAYGORODSKAYA, George Alexander. 1982. The methodology of intensive teaching of foreign languages: Textbook. For university teachers and students. Higher school. Moscow, Russia. $141 \mathrm{p}$.

KOLKOVA, Mikaeil Sultanbek (Ed). 2003. Teaching foreign languages. KARO. Saint-Petersburg, Russia. 320 p.

KRYUCHKOVA, Elena Sergei. 2018. Modular training of future teachers with the use of information technologies in the conditions of virtual academic mobility. In: Modern Humanities Success. Issue 4, pp. 9-14.

KSENZOVA, Gulnura Yuryevna. 2001. Promising school technology: a teaching tool. Pedagogical Society of Russia. Moscow, Russia. 224 p.

KUZNETSOV, Anna Albina; IGNATYEVA, T.A; KUZNETSOV, A.O. 2018. Strategy and key elements of competitiveness. In: Modern Economy Success. Issue 1, pp. 25-29.

LARSKIKH, Valery Pavel; LARINA, I.B. 2017. Holding an elective course with the purpose of formation communicative culture of a future bachelor.In: Modern Scientist. Issue. 6. pp. 168-171.

OSIPOVA, Munirovich Barbara. 2018. Tendencies of development of educational practice of the modern educational organizations. In: Modern Humanities Success. Issue 1, pp. 10-13.

SCHERBAKOVA, Natalia Irina. 2002. Goals and objectives of teaching a foreign language in a secondary vocational educational institution. In: Secondary vocational education. No. 2, pp. 33.

SERGEEVA, Mikaeil George; TRUBAKOVA, D.I. 2017. Teacher's Reflection Formation as Factor of Effectiveness Children's Social Intelligence Forming. In: Modern Scientist. Issue 7, pp. 62-64.

SHCHERBAKOVA, Natalia Ivanovna; ZVENIGORODSKAYA, N.S. 2003. Practical English grammar. Agricultural Academy. Moscow, Russia. 84 p. 
YAZOVSKIKH, Elena Valery. 2018. Employment of graduates as one of the efficient activity indicators of the higher educational establishment, ural federal university is taken as an example processes. In: Modern Economy Success. Issue. 1, pp. 33 -37.

ZIMNIAYA, Inna Anatolyevna. 2000. Pedagogical psychology. Textbook for higher schools. Logos. Moscow, Russia. 384 p. 

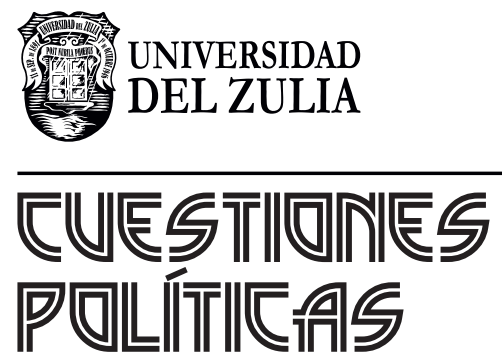

Vol. $37 \mathrm{~N}^{\circ} 64$

Esta revista fue editada en formato digital y publicada en junio de 2020, por el Fondo Editorial Serbiluz, Universidad del Zulia. Maracaibo-Venezuela 